\title{
Bacillus subtilis for biological protection of Taxus baccata $L$. in landscape gardens
}

\author{
Sergey Kopyltsov*, and Anna Gneush \\ Kuban state agrarian University, Department of Processing Technologies, 350044 Kalinina str., 13, \\ Krasnodar, Russia
}

\begin{abstract}
The fungistatic effect of the endophytic strain of Bacillus subtilis in park stands of Taxus baccata L. var. "Fastigiata". The study used trees in park stands with symptoms of damage by the phytopathogenic fungus Cryptocline taxicola (All.) Petr. It was found that treatment of shoots with a suspension of microorganisms Bacillus subtillis strain krd-20 in the autumn and spring prevented the development of the disease and the fall of needles. RAPD-PCR was used to determine that the strain was capable of endophytic development and was preserved in the coniferous tree for at least six months.
\end{abstract}

\section{Introduction}

Yew (Taxus baccata (Lindl.)) it is an ornamental coniferous plant, widely used in park landscapes [1]. The yew tree is also widespread in the natural forest biogeocenoses of Russia, in particular in the North-Western Caucasus. To date, this species belongs to the protected plants with the status - declining in number.

Among the most common diseases for yew are "shütte" - a symptomatic group of diseases caused by various phytopathogenic fungi. Thus, among the most common phytopathogenic fungi for yew, Alternaria alternata, Phomopsis juniperivora, Fusarium spp., as well as Phomopsis juniperivora and Sclerophoma pityophila have been identified [2]. The phytopathogen Phytophthora ramorum has a local distribution in yew stands [3].

In addition to these species, in recent decades, there have been reports of the development of the phytopathogen Cryptocline taxicola (All.) Petr. on the yew tree for the territory of Western Europe and North America [4,5,6].

This disease is manifested in single necrotic spots on the coniferous and yew stems of the current year. As the phytopathological process develops, the affected vegetative organs undergo complete necrosis. On the upper and lower side of the needles, micromycete sporebearing organs are formed. When the air is sufficiently humidified, the conidia of the fungus develop into noticeable beige pustules on the acervules that tear the integumentary tissue [5]. Affected plants lose up to $90 \%$ of their needles along with their shoots.

An effective way to control this phytopathogen is the use of fungicides, including biofungicides, especially in park areas with a high anthropogenic load. One of the main producers of biofungicides are microorganisms of the genus Bacillus [7-10]. Especially

* Corresponding author: bioorigin@yandex.ru 
promising are endophyte symbionts that penetrate the plant tissue and exist in it without causing harm [11, 12]. The possibility of developing endophytes in coniferous plants was also shown in the work of H. Izumi et al. [13]. Due to their effectiveness and Toxicological

safety, biofungicides based on Bacillus subtilis and other species of this genus are promising and used [14].

Until now, the scientific literature has not found a description of this disease of yew in Russia. This is probably due to the previously not significant spread of this disease. However, in recent decades, yew has become increasingly used in park landscapes. Seedlings come mainly from the territory of European countries where this disease is developing. In this regard, the development of yew protection tools, including the use of microbiological agents, is timely.

The aim of the study was to study the interaction of Bacillus subtilis strain with Yew in the "endophyte-plant" system to prevent the development of phytopathological process by the pathogen Cryptocline taxicola.

\section{Materials and Methods}

The research was carried out in 2018-2019 in the conditions of artificial plantings in the city of Krasnodar, where the death of needles and branches of Taxus baccata var. Fastigiata has been observed for more than five years. Yew specimens in the number of 10 trees aged from 10 to 15 years were subjected to phytosanitary examination. The trees studied had one -, two-and three-year-old live needles with local foci of infection, as well as two-and threeyear-old completely brown needles and shoots still attached to the branch.

Identification of the pathogen Cryptocline taxicola was carried out by macroscopic features on plant material and microscopy of spore-bearing organs.

The trees studied were randomly divided into two groups. The first group was used as a control, the second group was subjected to double treatment with Bacillus subtillis suspension. The first treatment was carried out in the autumn period at the end of the growing season, the second - in early spring (the second decade of March) of the following year before the appearance of shoots of the current year.

The treatment was performed by spraying a suspension with a concentration of bacterial cells of $6 * 10^{8} \mathrm{CFU} / \mathrm{ml}$. The study used Bacillus subtillis subsp. subtilis strain krd-20 from the collection of the Department of biotechnology, biochemistry and biophysics of the Kuban state agrarian University. The strain was identified based on a comparison of its 16S rDNA sequence in the GenBank database BLAST program (NCBI). This strain has antagonistic activity in relation to the reference strains of phytopathogenic fungi Fusarium sp., Alternaria sp., Phomopsis sp., determined by the method of counter-growth on the nutrient medium.

To isolate endophytic bacteria from the needles, the plant material was washed in running water, then their surface was disinfected in 75\% ethanol for 1 minute, and then washed again in sterile distilled water. After drying, the material was placed on a potato dextrose agar medium (PDA) and incubated at a temperature of $27^{\circ} \mathrm{C}$.

Discrimination of Bacillus isolates in determining the ability to endophytic development was performed by RAPD-PCR. RAPD primer 1254 with a 5'-CCGCAGCCAA-3' nucleotide sequence was used for fingerprint PCR [15]. Amplification was performed in 25 $\mu \mathrm{l}$ of a reaction mixture containing $2.5 \mu \mathrm{l} 10$ times. Taq buffer; $6 \mathrm{~mm} \mathrm{MgCl}$; $0.2 \mathrm{~mm}$ mixture of deoxynucleoside triphosphates; $0.2 \mu$ m primer (RAPD1254); 1 unit of Taq DNA polymerase and $2 \mu \mathrm{l}$ of genomic DNA as a matrix. Amplification conditions: initial denaturation at $94{ }^{\circ} \mathrm{C}-2 \mathrm{~min}$; 45 cycles of denaturation at $95{ }^{\circ} \mathrm{C}-1 \mathrm{~min}$, annealing at $36{ }^{\circ} \mathrm{C}-1$ 
min, synthesis at $72{ }^{\circ} \mathrm{C}-2 \mathrm{~min}$; final cycle at $72{ }^{\circ} \mathrm{C}$ for $10 \mathrm{~min}$. Electrophoresis of fragments was performed in agarose gel.

\section{Results and Discussion}

Phytosanitary examination of yew trees showed that in a mild winter, signs of $C$. taxicola damage persist on the vegetative organs of the previous vegetative period. In arid conditions, the fruit bodies of the pathogen in the place of pustules had a black and wrinkled appearance (Fig. 1 A). With the beginning of vegetation, the affected needles fell off, and the bare shoots died (Fig. 1 B).
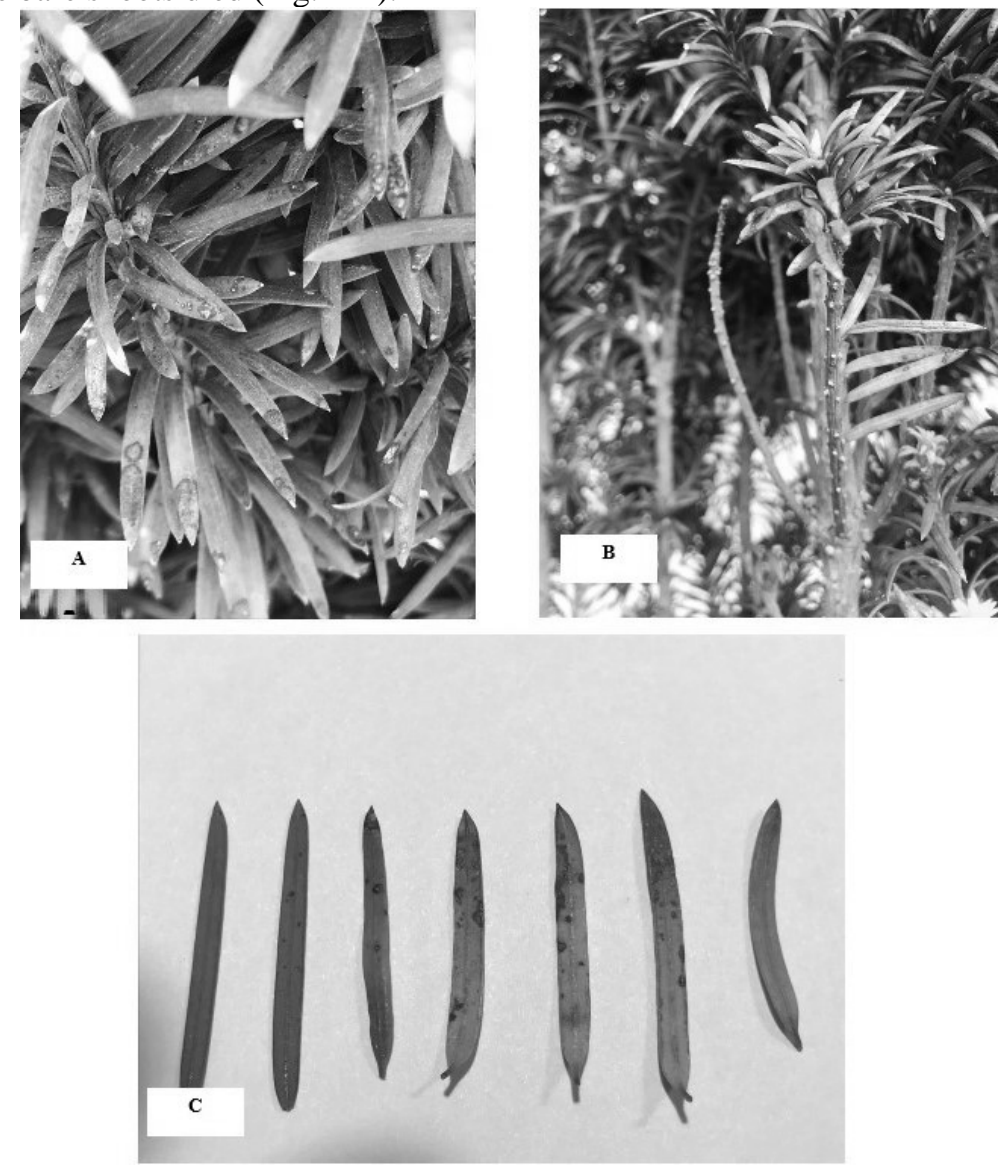

Fig. 1. Manifestation of C. taxicola on the vegetative organs of Taxus baccata. A) Acervules on needles of needles; B) Stripping of shoots and their subsequent death; C) the Degree of necrotic lesionof needles in the development of pustules.

Pustules on conifers were located locally with different intensity of development and degree of necrotizing (Fig. $1 \mathrm{C}$ ). Mass fall of the affected needles was observed with the beginning of regrowth of shoots of the current year.

The experimental group of trees was treated with a suspension of B. subtillis subsp. subtilis strain krd-20 in the autumn at the end of the vegetation of the previous year and in March of this year before the beginning of vegetation and shoots regrowth. In the first decade of may, with the beginning of shoots regrowth, a microbiological study of the internal tissues of needles of the first year was performed. Morphologically comparable 
strains were extracted from the surface-sterilized needles on the PDA with the one used for processing.

To compare the strains isolated from the fermented substrate with the inoculated one,the genomic DNA of these strains was analyzed by RAPD-PCR using the RAPD1254 primer, which gives diffirenzing major bands when studying bacteria [15]. Presented in Fig. 2 the electrophoregram shows that 3 strains $(\# 2,4,6)$ out of 5 had RAPD profiles identical to the inoculant strain.

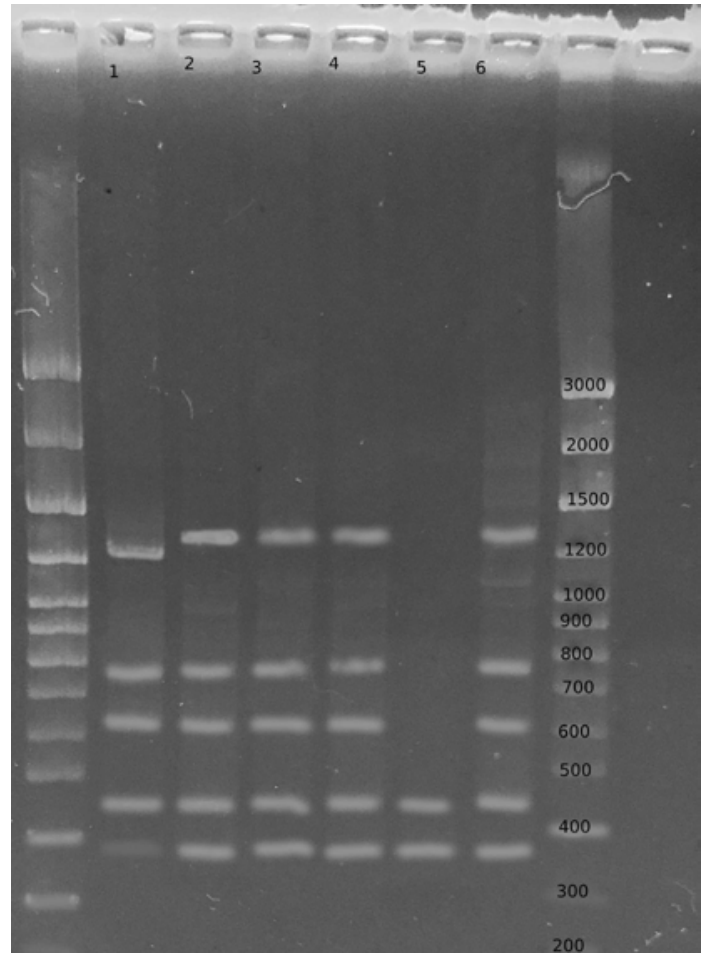

Fig. 2. PCR amplified fragments of Bacillus isolates with RAPD1254 primer: reference straininoculant - 3, isolates isolated from surface-sterilized needles: 1, 2, 4, 5, 6. Marker: Step100 Long.

The presented result indicates that after processing the vegetative organs of yew with bacterial suspension, the strain of $B$. subtillis subsp. subtilis, krd-20 is able to develop inside plant tissues as an endophytic microorganism.

Phytopathological examination of the study group of trees in may showed that individuals of the experimental group of yew treated with a biofungicide based on $B$. subtillis subsp. subtilis, krd-20, had only single needles of needles with symptoms of C. taxicola lesions, preserved from the previous year. A group of trees of the control variant without treatment at the time of regrowth of shoots of the current year had a mass fall of needles with signs of necrosis and nil pustules of $\mathrm{C}$. taxicola. The bared shoots did not have a lateral growth formation either in the current or next year. This, accordingly, limited the crown's fullness. Bacillus subtilis subsp. subtilis, krd-20 deposited by the All-Russian Collection of Microorganisms of the IBFM im. Scriabina, VKM B-3516D.

Thus, it is established that the use of the endophytic strain of B. subtillis subsp. subtilis, krd-20 as a biofungicide is an effective means of protecting Taxus baccata from thephytopathogen C. taxicola. 


\section{References}

1. P.A. Thomas, A. Polwarta, Journal of Ecology, 91, 489-524 (2003). W. Mirski, Acta Agrobotanica, 61, 191-197 (2008).

2. L. Pehl, A. Wulf, Nachrichtenbl. Deut. Pflanzenschutzd, 54, 266-268 (2002).

3. C.R. Lane, P.A. Beales, K.J.D. Hughes, J.A. Tomlinson, A.J. Inman, K. Warwick, New Disease Reports 8, 36 (2004).

4. N. Bukvayova, Plant Protect. Sci., 43, 122-124 (2007).

5. V. Vujanovic, M. St-Arnaud, Plant Disease, 85 (8), 922 (2001).

6. Alvarez, M. Castro, A. Principe, G. Borioli, S. Fischer, G. Mori, E. Jofre, J Appl Microbiol, 112, 159-174 (2012).

7. Santoyo, M. D. Orozco-Mosqueda, M. Govindappa, Biocontrol Sci Technol, 22, 855872 (2012).

8. K. G. Surendra, S. B. Marshall, Microbiological Research, 172, $79-87$ (2015).

9. Hwang, H. Jeong, Prev Nutr Food Sci, 17, 64-70 (2012).

10. D. Hazarika, G. Goswami, T. Gautom, A. Parveen, P. Das, M. Barooah, R. Boro, BMC Microbiology, 19:71, 115-121, (2019).

11. G. Santoyo, G. Moreno-Hagelsieb, O-MM. del Carmen, BR. Glick, Microbiol Res, 183, 219-224 (2016).

12. H. Izumi, IC. Anderson, K. Killham, ER. Moore, Can J Microbiol, 54(3), 173-181, (2008).

13. R. Lahlali, G. Peng, B. D. Gossen,L. McGregor, F. Q. Yu, R. K. Hynes, S. F. Hwang,

14. M. R. McDonald, S. M. Boyetchko, Phytopathology, 103, 245-254, (2013).

15. Miteva, S. Selenska-Pobell, V. Mitev, J. Appl. Microbiol, 86, 928-936, (1999). 